\title{
Human nature, freedom and dignity in China and Europe
}

\author{
Torbjörn Lodén
}

Received: 3 December 2013/Revised: 10 February 2014/ Accepted: 11 February 2014/

Published online: 8 May 2014

(C) Academy for International Communication of Chinese Culture and Springer-Verlag Berlin Heidelberg 2014

\begin{abstract}
In this paper, the author argues that the differences between Chinese and Western culture should be seen as variations on common themes rather than as absolute dichotomies. He describes how the ideas 'human nature', 'freedom' and 'dignity' are expressed in the cultural traditions of China and Europe and finds that in both traditions the values of freedom and dignity are anchored in human nature. Although there is no word in the lexicon of Classical Chinese that corresponds closely to the English word 'freedom', he argues that freedom in the sense that each living creature should have the freedom to live according to develop according to his or her specific nature was central to the tradition of Zhuangzi. With reference to the writings of Lu Xun and George Orwell he points out that far too often the beautiful ideas of freedom and dignity are used to conceal the ugly reality of degradation and oppression rather than to serve as levers for social improvement.
\end{abstract}

Keywords Freedom $\cdot$ Dignity $\cdot$ China $\cdot$ Europe $\cdot$ Human nature

The noble man is no utensil, said Confucius. Human beings should be regarded as ends and not as means, argued Immanuel Kant. This idea expressed somewhat differently by one Chinese and one European philosopher has deep roots both in China and in Europe. ${ }^{1}$

\footnotetext{
1 The Analects, 2:12. Kant's idea was that a rational being must never be treated only as a means. What he said was: "So act as to treat humanity [Menschheit], whether in your own person or in that of any other, always at the same time as an end, and never merely as a means." Quoted from Copleston (1964, p. 120) For a contemporary discussion of the implications of saying that it is the humanity in the human being shat should be treated as an end, see Hill (1992, pp. $38 \mathrm{ff})$.
}

T. Lodén $(\bowtie)$

The Department of Oriental Languages, Stockholm University, Stockholm, Sweden e-mail: Luoduobi@gmail.com 
Like two big rivers cultural traditions of China and Europe flow through the historical landscape. To chart in detail their respective courses, from their beginnings in prehistoric times until today, is an arduous task that has yet by no means been fully accomplished. But at least we can see that they have collected their waters from many different sources and have also themselves given rise to innumerable tributaries, linking up with other cultures and with each other. For at least 2000 years there have been contacts between them.

Throughout history, these contacts have made people in Europe marvel at how different the Chinese are, and likewise people in China have been amazed to observe how different the Europeans are. Sometimes the different "other" has been conceived as inferior, sometimes as superior. But contacts have also meant influence, so we cannot really speak of either a pure Chinese or a pure European tradition. Both traditions are by their nature hybrids.

Of course, in many ways the two traditions are different. There are also considerable differences within each cultural tradition and even between individual human beings. Indeed, in comparing "China and the West" or even "the East and the West" one often underestimates the internal diversity of the East and the West while exaggerating the differences between the two. It seems to me that the differences within the one tradition are often as great as the differences between the two traditions. But whether we speak about differences within a tradition or between traditions these differences seem to be not so much absolute dichotomies as variations on common themes. The intercultural differences do not result in an unbridgeable gap.

By virtue of their mutual influence the traditions of China and Europe are akin, they are "relatives". More importantly, they share similar features which cannot be attributed to mutual influence but which rather seem to be rooted in some fundamental likeness of human beings that transcends cultural and historical boundaries. We may see these similarities as rooted in universal human nature.

The references to Confucius and Kant at the beginning of the article are one important example of such a similarity. These views express, it seems to me, a humanism which has been expressed with different sets of concepts but which still shares some core beliefs and values that bridge the gap between the two traditions and are very much relevant in facing the challenges of today.

\section{Human nature, freedom and dignity in Chinese tradition}

To regard every human being not as a utensil but as an end is to recognize the dignity of every individual. It signifies an ethical stance, with far-reaching implications as to how we should behave towards one another, but it also expresses some beliefs about what it means to be human.

In the Chinese tradition of Confucianism, Mencius described more than two millennia ago how human beings are born with a moral capacity to distinguish between good and evil, right and wrong and with a natural inclination to take delight in what is good and right and to abhor what is evil and wrong. We should not discard this ethical optimism as naïve. Mencius realized how human beings are prone to err, but he was convinced that compassion was innate, and he considered compassion to be the 
foundation of morality. His parable about an infant about to fall into a well is very forceful:

Suppose a man were, all of a sudden, to see a young child on the verge of falling into a well. He would certainly be moved to compassion, not because he wanted to get in the good graces of the parents, nor because he wished to win the praise of his fellow villagers or friends, nor yet because he disliked the cry of the child. From this it can be seen that whoever is devoid of the heart of compassion is not human, whoever is devoid of the heart of courtesy and modesty is not human, and whoever is devoid of the heart of right and wrong is not human. ${ }^{2}$

If human beings were allowed to grow up under decent circumstances and nourish their natural inclinations and do their best to acquire knowledge and understanding, then they would, he believed, also do what is good and right. This is the essential meaning of his belief in the goodness of human nature.

“Noble persons"一junzi 君子 in Chinese-are people who have realized the moral potential inherent in all human beings. They are no "utensils". People, and especially “noble persons", deserve "respect"—jing 敬 —and they should themselves be respectful. In this ethical universe, where not being reduced to a "utensil" is the hallmark of realized potential and where "respect" should be prominent in human relations, we can say that human beings possess dignity, although we may look in vain for close equivalents to the word "dignity" in the lexicon of the classical Chinese language.

"Respect" in the Confucian tradition is often discussed in a hierarchic context: respect is something that a person below shows a person above, and so one could say that it implies only that those high up on the social ladder possess dignity and not that dignity is a quality shared by all humans. Yet we should not forget that the hierarchic tendency of Confucianism, although certainly dominant, especially in Confucianism as the political ideology of the imperial state, coexists with a more egalitarian tendency that has found expression in the writings of Confucius thinkers, ever since Confucius himself who said: "That which you do not want others to do to you, you should not do to them." Much later than Confucius, Huang Zongxi in the seventeenth century discussed rulers and subjects in terms of "master" and "tenant":

In ancient times the people were considered the master, and the prince was the tenant. The prince spent his whole life working for the people. Now the prince is master, and the people are tenants. That no one can find peace and happiness anywhere is all on account of the prince. In order to get whatever he wants, he maims and slaughters the people and breaks up their families - all for the aggrandizement of one man's future. Without the least feeling of pity, the prince says, "I am just establishing an estate for my descendants." Yet when he has established it, the prince still extracts the very marrow from people's bones, and takes away their sons and daughters to serve his own debauchery. It seems entirely proper to him. It is, he says, the interest on his estate. Thus he

\footnotetext{
2 Trans. Lau (2003, p. 73).
} 
who does the greatest harm in the world is none other than the prince. If there had been no rulers, each man would have provided for himself and looked to his own interests. How could the institution of rulership have turned out this way? $?^{3}$

Huang would certainly have subscribed to the notion that respect is something that not only leaders but also so-called ordinary people deserve.

The absence of a word for a notion or a phenomenon does not necessarily imply the absence of the phenomenon. We may find many examples of this within a cultural tradition. In Europe the word "humanism", and its equivalents, is much later than important examples of humanism. Similarly, in cross-cultural comparisons we may find that words and notions discussed in one culture do not have close lexical equivalents in the other, but the basic ideas and phenomena that the words try to capture may still be there. For example, "freedom" does not have a close equivalent in the classical Chinese lexicon, but it would be mistaken to conclude that there was no notion of freedom or that it was not considered important as a phenomenon.

Of course, the word "freedom" and its equivalents have different though related meanings. One core meaning of freedom is not to be prevented from doing what one wishes to do and to live in accordance with one's basic wishes and inclinations. This is an idea that is very much present in the Chinese tradition of Daoism. Zhuang Zi says:

Once a seabird alighted outside the Lu capital. The Marquis of Lu escorted it to the ancestral temple, where he entertained it, performing the Nine Shao music for it to listen to and presenting it with the meat of the Tailao sacrifice to feast on. But the bird only looked dazed and forlorn, refusing to eat a single slice of meat or drink a cup of wine, and in three days it was dead. This is to try to nourish a bird with what would nourish you instead of what would nourish a bird. If you want to nourish a bird with what nourishes a bird, then you should let it roost in the deep forest, play among the banks and islands, float on the rivers and lakes, eat mudfish and minnows, follow the rest of the flock in flight and rest, and live any way it chooses. [...] Fish live in water and thrive, but if men tried to live in water they would die. Creatures differ because they have different likes and dislikes. Therefore the former sages never required the same ability from all creatures or made them all do the same ting. 4

The notion of "free and easy wandering", to use Burton Watson's translation of xiaoyao 逍遥, is very much at the core of Zhuang Zi's thinking. It means that we should live in accordance with what is natural and that we should be allowed to do so, without the interference of people who oppose what is natural. For me this is indeed a plea for freedom.

\footnotetext{
3 Trans. de Bary (1993, p. 92).

4 Trans. Watson (1968, pp. 194-195).
} 
Zhuang Zi's plea for freedom to live in accordance with one's particular nature is also a plea for dignity. No one has the right to try to make others act against their own nature.

So far my main purpose has been to show that we find a concern in Chinese tradition with human dignity and freedom that is based on notions of human nature. I have cited a couple of examples from Confucianism and Taoism, but I could of course also have found examples in Buddhism and in popular religion. Not least the centrality of ancestral worship in Chinese culture demonstrates the importance of upholding the dignity of human beings.

\section{Human nature, freedom and dignity in European tradition}

Just as in Chinese tradition, ethics in European tradition has been based on concepts of human nature. For example, in the tradition the Icelandic Old Norse poem "Havamal" in the Poetic Edda we find the "thesis that human nature is the bedrock on which the pillars of moral philosophy must rest." 5

In even more elaborate form we find this notion in classical Greek philosophy. Socrates and Plato were convinced that it was natural for humans to wish to do good, to will the good. It was difficult for them to conceive of a person who knowingly and deliberately acts against what is good and right. In this they very much resembled Mencius.

Aristotle was less optimistic in this regard and was very much aware that humans have a choice of doing what is good or what is not good and may even desire what is not good. In this there is a resemblance between Aristotle and the Chinese philosopher Xun $\mathrm{Zi}$, the third major Confucian thinker to emerge on the historical scene, who based his doctrine of the evil of human nature on the observations that human beings often express selfish desires.

In European tradition we may since early times find a focus on the importance of freedom. The yearning for freedom emerged as a reaction against oppression, and to be free was a way to maintain and safeguard one's dignity. This perspective of freedom and dignity is very evident in the Icelandic tradition. As we know, the sagas project the image of originally free men who had come to Iceland to escape the tyranny of the Norwegian King Harald Fair-hair. For example, in The Saga of Hord and the People of Holm we may read:

Most of Iceland was settled in the days of Harad Fair-hair. People would not endure his oppression and tyranny, especially those who belonged to aristocratic families and who had ambition and good prospects. They would rather leave their property in Norway than suffer aggression and injustice - whether from a king or from anyone else. ${ }^{6}$

In the sagas we meet a preoccupation, bordering on obsession, with guarding one's honour and dignity (sómi, saemd, virding etc.). Humiliation was not to be accepted,

\footnotetext{
5 See Johnson (1938).

${ }^{6}$ Kellogg (2001, p. xxxvii).
} 
and even revenge was recommended as a means to restore one's honour. ${ }^{7}$ One may easily get the impression that safeguarding one's own honour and dignity was a much more central concern than respecting the dignity of others.

In European tradition the notions of choice, free choice and free will have for more than two millennia been at the core of philosophical and religious deliberations on ethics. As compared with the Chinese, this focus is probably one characteristic feature of the European tradition.

On the one hand we find both in the secular and the Christian tradition the idea that human beings are disposed to do what is good. On the other hand, many thinkers and theologians have also emphasized that what is not good or evil may also be attractive. In Christian terms Satan subjects people to the temptations of evil. Very often the evil has been associated with sensuous desire whereas the good will has been described as somehow residing beyond the realm of the senses.

In European tradition, and perhaps especially so in Christianity, the struggle between good and evil is conceived as an internal struggle within the individual human being, who is seen as equipped with a free will to choose between good and evil, and this makes him or her a responsible moral agent. In the Christian tradition the notion of free will was first brought to the foreground by St. Augustine in the fourth century A.D. St. Augustine emphasized on the one hand that human beings have a free will, but he was also of the opinion that the human will by necessity seeks happiness and true happiness can only be found in God. Frederick Copleston explains succinctly how St. Augustine seeks to reconcile these two tenets of his thought:

The will necessarily seeks happiness, satisfaction, and de facto this happiness can be found only in God, the immutable Good, but man has not the vision of God in this life, he can turn his attention to and cling to mutable goods in place of God, and this "turning away and this turning to are not forced but voluntary actions". 8

Later in the mediaeval Christian tradition, St. Augustine's ideas were elaborated by many thinkers in the Christian tradition, for example by the great Thomas Aquinas, and the tension between the freedom to turn to or away from goodness and the natural inclination to seek the good very much remained in the foreground. In Protestant theology as articulated by Martin Luther and others, the idea that humans have a free will was questioned or even denied, while the grace of God was emphasized as the only way to attain salvation.

In the philosophical tradition outside the realm of theology the question of the free will has also been very central. Many thinkers have argued that unless man has a free will there can be no responsibility and no morality. As we know, Kant postulated free will as necessary for morality. But he also struggled to reconcile his idea of a free will with the notion of causality that David Hume and others in the empiricist tradition had developed: how can the human will be free if everything including every "willing" has a cause? Kant's solution was to place the free will in

\footnotetext{
${ }^{7}$ See, e.g., Hallberg (1956, pp. 88-103).

${ }^{8}$ Copleston (1962, p. 98).
} 
the world of the noumena, which was supposedly not subject to the causality that prevails in the world of the phenomena. For Kant and his followers the view of human beings as free and responsible moral agents has been an important basis for the notion of dignity as an inalienable feature of human life.

In the twentieth century Sartre and other existentialist philosophers argued that human beings have the freedom and the duty to define who they are, and that doing so is their most essential task. In the language of existentialism it is an essential feature of human life that "existence precedes essence".

While many thinkers in European tradition have struggled with the contradiction they have perceived between causality and free will, others have conceived causality as a prerequisite of freedom. For them, the essence of a free will has been to be able to do what one wants to do, and if they have focused on the willing as such they have also emphasized that freedom must involve the capacity to "steer", as it were, the will. The attempts to deny any contradiction between determinism and free will can be found most typically in the tradition of British empiricism. ${ }^{9}$

As far as freedom is concerned, the focus of the empiricists has often differed from those who have worried about the contradiction between causality and freedom. The latter have been most occupied with the problematique of the "willing" itself: how can my willing to do something be free if this willing can be shown to be a necessary result of some neurological process, itself subject to the laws of causality, in my brain?

For the advocates of freedom in the empiricist camp, the focus has rather been on the freedom to do what one actually wishes to do, no matter why one wishes to do it. The importance of this kind of freedom came to be emphasized in Europe especially from the Enlightenment onwards, as part of emerging modernity. Of course, from the point of view of ideology, freedom in this sense fitted the needs of the market economy, which became increasingly important in the process of industrialization and modernization.

John Stuart Mill, perhaps the most eloquent and important spokesman for human freedom in European tradition, represented this post-Enlightenment empiricist current of thought. In his view it was a misunderstanding to see a contradiction between free will and causality, but this problem was not his main concern. His most famous work On Liberty begins with the following words:

The subject of this Essay is not the so-called Liberty of the Will, so unfortunately opposed to the misnamed doctrine of Philosophical Necessity; but Civil, or Social Liberty; the nature and limits of the power, which can be legitimately exercised by society over the individual. ${ }^{10}$

Interestingly, as Max Lerner has pointed out, Mill emphasized that freedom was necessary for the growth of the person; it was "the frame [...] needed for fulfilment of potentials." In other words, Mill's argument for freedom was predicated on his understanding of human nature: only a free person would be able to develop his or her innate capabilities. No doubt, Zhuang Zi and his followers in China would have expressed their wholehearted agreement with Mill in this regard.

\footnotetext{
${ }^{9}$ Concerning free will and determinism, see Berofsky (1966).

${ }^{10}$ Lerner (1961, p. 255).
} 
Of course, the central position of freedom in Mill's thought was also based on his utilitarian view of the greatest happiness for the greatest number of people as the supreme good. Moreover, his emphasis on the importance of freedom also had very much to do with social progress and modernization. Like other liberals, he saw freedom both as something good in itself and as an instrumental value, which would promote the emergence of a more advanced and more civilized society.

\section{Words and facts, theory and practice}

I have chosen to try to structure my discussion of the Chinese and European traditions around the three concepts "human nature", "freedom" and "dignity". Of these "human nature" has a very close equivalent in the Chinese renxing 人性. The word "nature" goes back to the Latin "nascor", to be born, and similarly the Chinese xing refers to what is innate. However, as we have seen, "freedom" and "dignity" are words with no close equivalents in the classical Chinese tradition.

I could also have taken my point of departure in Chinese words with no precise equivalents in European languages. One such word is cheng 诚, which means honest and truthful, to others and to oneself, or qing 情, which means "feeling", but also "true nature" and "situation". Although these words lack precise equivalents in the lexicon of European languages, I am convinced that their meanings can be rendered pretty closely by means of explanations in European languages. There are no unbridgeable gulfs separating the conceptual words of Europe and pre-modern China.

In both Chinese and European traditions, ethical discussions have been based on concepts of human nature and emphasized the dignity and responsibility of the individual human beings, especially those human beings who have had a chance to develop their innate potential as moral agents. Freedom is a much more central concept in European than in Chinese tradition, but Zhuang Zi's notion of "free and easy wandering" implies a plea for the individual's freedom to behave and develop in accordance with his or her individual characteristics. And Confucius' dictum that the noble man is no utensil places "the noble man", that is the person who has had the chance to develop his or her potential, in what Kant would call the kingdom of ends, which is impossible to imagine without freedom.

Similarly in both Chinese and European traditions we may find the notions of human nature and human dignity denied and the view of freedom as an inalienable human right rejected.

Article 1 of the Universal Declaration of Human Rights adopted by the United Nations on December 10, 1948, says:

All human beings are born free and equal in dignity and rights. They are endowed with reason and conscience and should act towards one another in a spirit of brotherhood.

The concepts used in this article we associate with the European or Western tradition, but we can indeed find, as I hope I have demonstrated in this essay, the underlying ideas and values also in the Chinese tradition. 
When people are treated merely as means and not as ends, when poverty or oppression deprives people of their dignity, when people are not allowed the freedom to develop their talents and express themselves freely, we cannot say that this is because the ideas of human nature, freedom and dignity are missing from our cultural traditions.

Modernity has given rise to unprecedented material wealth and also incredible advances in science and technology as well as penetrating analyses of the human predicament and questions of value. Our world should therefore have reached a level of unprecedented civilization. But in spite of these advances that we associate with modernity, the past century has seen some of the most appalling examples of uncivilized behaviour: two world wars, genocide, extreme poverty existing side by side with extreme luxury, disregard for human rights and the like. In view of all examples of atrocities that people, even cultured people, have committed and continue to commit, it does not seem possible to uphold the notion of human nature as all good. But we do not have to reject Mencius' idea that human beings possess an innate capacity for goodness or Kant's assumption that we are equipped with an inherent "humanity" (Menschheit) which enables us to enter the kingdom of ends.

Human culture in different parts of the world has produced the ideas and values for a truly civilized life. But human culture has also produced ideas and values which are the seeds of oppression. ${ }^{11}$ It is our task to do our best to adopt the former and reject the latter. Sadly, far too often we seem to do the opposite.

In fact, our beautiful ideas of human dignity, freedom, equality and the like are even used to conceal the ugly reality of degradation and oppression, be it in China or in Europe. The words of the madman in Lu Xun's famous short story The Diary of a Madman reading his history book come to mind:

Scrawled all over each page are the words: "Confucian Virtue and Morality." Since I could not sleep anyway, I read intently half the night until I began to see words between the lines. The whole book was filled with the two words "Eat people". 12

Or we may think of the Party slogan in George Orwell's 1984:

WAR IS PEACE, FREEDOM IS SLAVERY, IGNORANCE IS STRENGTH

We may find solace and joy in the beautiful ideas found in the traditions of China and Europe. But we must also measure these ideas against the realities of the contemporary world and try to use them as a lever for change. In conclusion I wish to point to eight broad areas where the ideas of human nature, dignity and freedom that I have discussed in this essay stand in glaring contrast to the actual situation in the world:

\footnotetext{
11 A superb study of European tradition in this perspective is Popper (1947).

12 Lu (1980, p. 42).
} 
1. Human nature, dignity and freedom are not compatible with war. It is therefore our duty to see to it that war becomes an illegal and unacceptable means of conflict resolution.

2. Human nature, dignity and freedom are not compatible with extreme poverty. It is therefore our duty to work for a more just distribution of wealth and income in the world.

3. Human nature, dignity and freedom are not compatible with political and economic oppression. In the real world democracy will never be complete, but it is still our duty to promote democratic development for all nations. Generally, democracy is conceived as a system of government in one country, but the core ideas of democracy are also relevant on a global scale.

4. Human nature, dignity and freedom are not compatible with inhuman sanctions and punishments. It is therefore our duty to exert ourselves to a complete end to torture and to abolish the death penalty.

5. Human nature, dignity and freedom are not compatible with patriarchal oppression of women. It is therefore our duty to see to it that true equality of the sexes becomes an inalienable part of modern civilization.

6. Human nature, dignity and freedom are not compatible with sexual exploitation, and it is therefore our duty to stop the appalling practice of trafficking and other forms of sexual exploitation.

7. Human nature, dignity and freedom are incompatible with child abuse, and it is therefore our duty to see to it that the UN declaration of the rights of children is taken seriously and becomes implemented.

8. Finally, human nature, dignity and freedom are not compatible with destroying our environment, because for human life and society to prevail and develop there must be fresh air to breathe and fresh water to drink and land to cultivate, not only for us but also for our children and grandchildren. It is our duty to adopt those measures that are necessary to design ecologically sound ways of life which will protect our planet as a wonderful place to live for those who come after us.

The primary task for those of us who study the traditions of China and Europe is to deepen our understanding of these traditions and to explain them. As a sinologist working in Sweden I consider it my main task to do what I can to help people in Sweden understand Chinese culture. But we must not content ourselves with understanding our traditions and shut our eyes to the glaring discrepancies between the values we take pride in and the often ugly reality. We must point to these discrepancies and remind others and ourselves that as long as they persist they are an insult to those beautiful ideas of our traditions that we cherish.

\section{References}

Berofsky, B. (Ed.). (1966). Free will and determinism. New York, NY: Harper \& Row.

Copleston, F. (1962). A history of philosophy, vol. 2 Mediaeval philosophy, part I Augustine to Bonaventure. New York, NY: Image Books. 
Copleston, F. (1964). A history of philosophy, vol. 6. Modern philosophy, part II Kant. New York, NY: Image Books.

de Bary, W. T. (1993). Waiting for the dawn: A plan for the prince. Huang Tsung-hsi's Ming-i-tai-fang lu. New York, NY: Columbia University Press.

Hallberg, P. (1956). Den isländska sagan (The Icelandic saga). Stockholm: Bonniers.

Hill, T. E, Jr. (1992). Dignity and practical reason in Kant's moral theory. Ithaca, NY: Cornell University Press.

Johnson, S. (1938). Old norse and ancient greek ideals. Ethics, 49(1), 18-36.

Kellogg, R. (2001). Introduction to the Sagas of icelanders. New York: Penguin Classics.

Lau, D. C. (2003). Mencius Bilingual edition. Hong Kong: Chinese University Press.

Lerner, M. (Ed.). (1961). On liberty, in essential works of Johns Stuart Mill: Utilitarianism, autobiography, on lliberty, the utility of religion. New York, NY: Bantam Books.

Lu, X. (1980). A Madman's diary. In selected works, vol. 1. Beijing: Foreign Languages Press.

Popper, K. (1947). The open society and its enemies. London: Routledge \& Kegan Paul Ltd.

Watson, B. (1968). The complete works of Chuang Tzu. New York, NY: Columbia University Press. 